\title{
脱墨条件における有色染料の脱色性*
}

\author{
日本化薬株式会社 色材研究所 菅 谷 邦 夫
}

\section{Decolouration of Dye in Deinking Treatment}

\section{Kunio Sugaya}

Nippon Kayaku Co., Ltd. Color Chemicals Research Laboratory

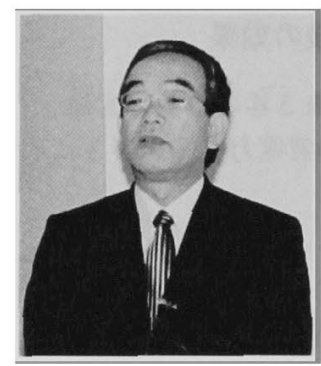

Recently environmental problems have been noticed grobally. In paper industries recycling of used paper becomes more important year after year for the protection of environment. Consequently the number of deinking facilities keeps increasing. Fluorescent whitening agents (for white paper) or paper dyes (for colouredpaper) are widely used for paper. These dyes or agents sometimes influence in recycling. As of now recycled paper mainly comes from newpaper including advertising paper and magazines.

Although colored wood-free paper which is tinted with paper dye are not so often recycled now, decolouration of paper dyes will be important. We previously studied decolouration by oxidizing or reducing method. This paper are reproting on decolouration of anionic direct dyes under deinking treatment conditions.

分類: $\mathrm{G}_{5}$ 脱インキ, $\mathrm{W}_{8}$ 染料・顔料

\section{1.はじめに}

染色の歴史は紀元前数千年にさかのほり，当時の染 料は草木などの天然色素であったが 1856 年に初めて 合成染料が開発され, 以後約 150 年経過した今日まで に多くの染料が開発されてきた。染料の開発は被色物 へ効率良く，無駄なく染着させることと染着した染料 が化学的, 物理的な過酷な条件にも充分耐え得る高堅 牢性を持つ事，そして色相が鮮やかである事などを目 標として進められてきている。

近年, 世界的に環境問題がクローズァップされ，そ の意識が高まる中で製紙業界に於いても自然保護や地 球温暖化改善を推進する上で, 紙のリサイクルへの気

*平成 12 年度年次大会講演（講演 No. C 5 )
運はますます高まっているのが現状であり，脱墨設備 も多くの製紙メーカーに設置されている。

紙の製品には增白を目的にした蛍光染料やカラフル さを目的にした有色染料等が広範囲に使用されている が高堅审性をポイントに開発されてきた染料をリサイ クルという観点から脱色 $\rightarrow$ 再生を如何にして可能にす るかというテーマの中から今回は一般的な脱墨処理条

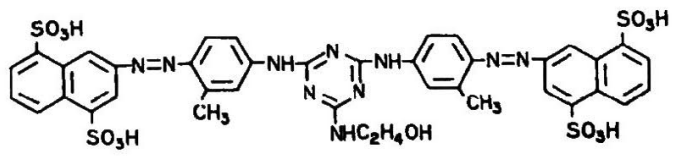

C.I. Direct Yellow 86

図 1 アニオン性直接染料基本構造 


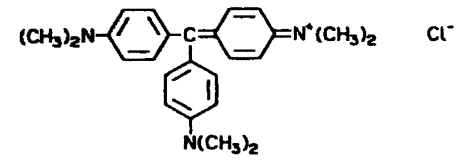

Methyl Violet

図 2 塭基性染料基本構造
表 1 薬品配合

\begin{tabular}{lrrrr}
\hline & 処方-1 & 処方-2 & 処方-3 & 処方-4 \\
\hline 脱 墨 剂 : & $0.3 \%$ & $0.6 \%$ & $0.3 \%$ & $0.6 \%$ \\
過酸化水素: & $0.0 \%$ & $0.0 \%$ & $0.05 \%$ & $2.0 \%$ \\
苛性ソーダ : & $1.0 \%$ & $1.0 \%$ & $1.0 \%$ & $1.0 \%$ \\
珪酸ソーダ: & $1.0 \%$ & $1.0 \%$ & $1.0 \%$ & $1.0 \%$ \\
\hline
\end{tabular}

表 2 Yellow-1 の結果

\begin{tabular}{|c|c|c|c|c|}
\hline \multirow{2}{*}{ 処 方 } & \multirow{2}{*}{ 温 度 } & \multirow{2}{*}{ 時 間 } & \multicolumn{2}{|c|}{ 脱色率（\%) } \\
\hline & & & 酸性紙 & 無サイス紙 \\
\hline 末処理 & & & 基 準 & 基 準 \\
\hline \multirow{5}{*}{ 処方- 1} & $40^{\circ} \mathrm{C}$ & 20 分 & 60 & 53 \\
\hline & \multirow{2}{*}{$60^{\circ} \mathrm{C}$} & 10 分 & 60 & 63 \\
\hline & & 20 分 & 65 & 63 \\
\hline & \multirow{2}{*}{$80^{\circ} \mathrm{C}$} & 10 分 & 60 & 72 \\
\hline & & 20 分 & 69 & 72 \\
\hline \multirow{5}{*}{ 処方 -2} & $40^{\circ} \mathrm{C}$ & 20 分 & 59 & 50 \\
\hline & \multirow{2}{*}{$60^{\circ} \mathrm{C}$} & 10 分 & 60 & 62 \\
\hline & & 20 分 & 65 & 63 \\
\hline & \multirow{2}{*}{$80^{\circ} \mathrm{C}$} & 10 分 & 60 & 72 \\
\hline & & 20 分 & 64 & 71 \\
\hline \multirow{5}{*}{ 処方 -3} & $40^{\circ} \mathrm{C}$ & 20 分 & 54 & 55 \\
\hline & \multirow{2}{*}{$60^{\circ} \mathrm{C}$} & 10 分 & 65 & 64 \\
\hline & & 20 分 & 70 & 65 \\
\hline & \multirow{2}{*}{$80^{\circ} \mathrm{C}$} & 10 分 & 76 & 76 \\
\hline & & 20 分 & 78 & 74 \\
\hline \multirow{5}{*}{ 処方 -4} & $40^{\circ} \mathrm{C}$ & 20 分 & 43 & 55 \\
\hline & \multirow{2}{*}{$60^{\circ} \mathrm{C}$} & 10 分 & 63 & 63 \\
\hline & & 20 分 & 70 & 65 \\
\hline & \multirow{2}{*}{$80^{\circ} \mathrm{C}$} & 10 分 & 75 & 76 \\
\hline & & 20 分 & 78 & 78 \\
\hline
\end{tabular}




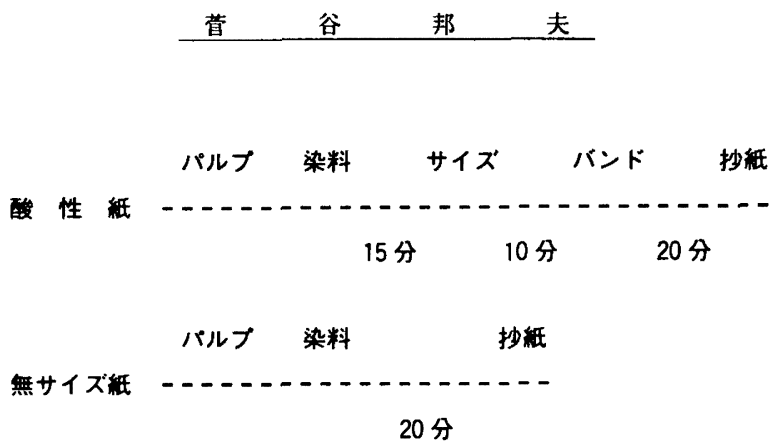

図 3 添加時間

表 3 Yellow-2 の結果

\begin{tabular}{|c|c|c|c|c|}
\hline \multirow{2}{*}{ 処 方 } & \multirow{2}{*}{ 温 度 } & \multirow{2}{*}{ 時 間 } & \multicolumn{2}{|c|}{ 脱色率（\%） } \\
\hline & & & 酸性紙 & 無サイズ紙 \\
\hline 未好理 & & & 基 準 & 基 準 \\
\hline \multirow{5}{*}{ 処方-3 } & $40^{\circ} \mathrm{C}$ & 20 分 & 2 & 15 \\
\hline & \multirow{2}{*}{$60^{\circ} \mathrm{C}$} & 10 分 & 9 & 16 \\
\hline & & 20 分 & 4 & 10 \\
\hline & \multirow{2}{*}{$80^{\circ} \mathrm{C}$} & 10 分 & 17 & 20 \\
\hline & & 20 分 & 11 & 17 \\
\hline \multirow{5}{*}{ 処方 -4} & $40^{\circ} \mathrm{C}$ & 20 分 & 2 & 17 \\
\hline & \multirow{2}{*}{$60^{\circ} \mathrm{C}$} & 10 分 & 5 & 13 \\
\hline & & 20 分 & 14 & 14 \\
\hline & \multirow{2}{*}{$80^{\circ} \mathrm{C}$} & 10 分 & 16 & 17 \\
\hline & & 20 分 & 16 & 17 \\
\hline
\end{tabular}

件において直接性アニオン染料がどの程度脱色するか について検討した。

\section{2. アニオン性直接染料の棈造}

基本的な棈造は図 1 に示したように，直線状である ことが特徴でしかも他種属の染料に較べ比較的大きな 分子量を持っている。比較参考までに紙着色用として 今でも使用されている塩基性染料の代表的な構造を図 2 に示す。

\section{3. 検 討条件}

\section{1 試験の手順}

1）酸性紙，無サイス紙を必要枚数染色。その中の 1 枚は乾燥まで行い脱色率测定基华用の未処理紙とす
る。

2）その他の染色紙は乾燥せず湿閏状態で薬品処理 を行う。

3）薬品処理した染色紙は抄紙 $\rightarrow$ 乾燥後未処理紙を 含め測色機による搌度测定にて脱色率を算定する。

3.2 染色紙作成

3.2 .1 供試染料，及び染色淈度

- KAYAKU Yellow-1 1.0\%

- KAYAKU Red-1 2.5\%

- KAYAKU Blue-1 $1.5 \%$

3.2 .2 染色条件

・パ ル プ:LBKP (フリーネス $300 \mathrm{ml}$ )

- 坪 量: $100 \mathrm{~g} / \mathrm{m}^{2}$

・パルプ浱度 : $3 \%$ 
表 4 Red-1の結果

\begin{tabular}{|c|c|c|c|c|}
\hline \multirow{2}{*}{ 処 方 } & \multirow{2}{*}{ 温 度 } & \multirow{2}{*}{ 時 間 } & \multicolumn{2}{|c|}{ 脱色率 (\%) } \\
\hline & & & 酸性紙 & 無サイズ紙 \\
\hline 末処理 & & & 基 準 & 基 準 \\
\hline \multirow{5}{*}{ 処方 -1} & $40^{\circ} \mathrm{C}$ & 20 分 & 68 & 35 \\
\hline & \multirow{2}{*}{$60^{\circ} \mathrm{C}$} & 10 分 & 64 & 59 \\
\hline & & 20 分 & 69 & 59 \\
\hline & \multirow{2}{*}{$80^{\circ} \mathrm{C}$} & 10 分 & 73 & 69 \\
\hline & & 20 分 & 79 & 70 \\
\hline \multirow{5}{*}{ 処方 -2} & $40^{\circ} \mathrm{C}$ & 20 分 & 68 & 35 \\
\hline & \multirow{2}{*}{$60^{\circ} \mathrm{C}$} & 10 分 & 67 & 55 \\
\hline & & 20 分 & 73 & 52 \\
\hline & \multirow{2}{*}{$80^{\circ} \mathrm{C}$} & 10 分 & 73 & 63 \\
\hline & & 20 分 & 79 & 71 \\
\hline \multirow{5}{*}{ 処方 -3} & $40^{\circ} \mathrm{C}$ & 20 分 & 67 & 45 \\
\hline & \multirow{2}{*}{$60^{\circ} \mathrm{C}$} & 10 分 & 76 & 56 \\
\hline & & 20 分 & 81 & 60 \\
\hline & \multirow{2}{*}{$80^{\circ} \mathrm{C}$} & 10 分 & 85 & 76 \\
\hline & & 20 分 & 87 & 74 \\
\hline \multirow{5}{*}{ 処方 -4} & $40^{\circ} \mathrm{C}$ & 20 分 & 69 & 45 \\
\hline & \multirow{2}{*}{$60^{\circ} \mathrm{C}$} & 10 分 & 75 & 55 \\
\hline & & 20 分 & 81 & 58 \\
\hline & \multirow{2}{*}{$80^{\circ} \mathrm{C}$} & 10 分 & 86 & 75 \\
\hline & & 20 分 & 88 & 75 \\
\hline
\end{tabular}

・サイス郕：1％（ロジン 対乾媒パルブ重量）

\section{‥酸性紙のみ添加}

・硫酸バンド：3\%（対乾燥パルプ重量）…酸性紙 のみ添加

・時間：図3参照。

3.3 脱晴条件

3.3.1 使用薬品

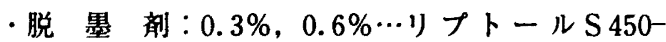

$$
\text { ライオン(侏) }
$$

-過酸化水素: $0.0 \%, 0.05 \%, 2.0 \%$

・苛性ソー夕: $1.0 \%$

・珪酸ソータ: $1.0 \%$

$\cdot \mathrm{pH}$

$$
: 10.5 \% 11.0
$$

\subsection{2 蒋品配合}

菜品配合を表 1 に示す。処方 $-1,2$ ：染料を分解・脱 色させる作用を持つ過酸化水素を除き脱墨郕の添加量 を変えその染料脱色性を観る。処方-3,4：脱墨処理に おける一般的な蒋品添加量において脱墨剂, 及び過酸 化水素のそれぞれ最小, 最大添加における脱色性を観 る。

\subsection{3 処理温度及び時間}

処理温度は $40^{\circ} \mathrm{C}, 60^{\circ} \mathrm{C}, 80^{\circ} \mathrm{C}$, 処理時間は 10 分, 20 分（但し $40^{\circ} \mathrm{C}$ は 20 分のみ）である。

\subsection{4 脱色率算出}

1）未処理紙を 100 とした時の処理紙の溇度を測色 機にて測定 


营谷 帮 夫

表 5 Blue-1の結果

\begin{tabular}{|c|c|c|c|c|}
\hline \multirow{2}{*}{ 処 方 } & \multirow{2}{*}{ 温 度 } & \multirow{2}{*}{ 時＼cjkstart間 } & \multicolumn{2}{|c|}{ 脱色率 (\%) } \\
\hline & & & 酸性紙 & 無サイズ紙 \\
\hline 未処理 & & & 基＼cjkstart準 & 基 準 \\
\hline \multirow{5}{*}{ 処方 -1} & $40^{\circ} \mathrm{C}$ & 20 分 & 22 & 12 \\
\hline & \multirow{2}{*}{$60^{\circ} \mathrm{C}$} & 10 分 & 20 & 15 \\
\hline & & 20 分 & 25 & 13 \\
\hline & \multirow{2}{*}{$80^{\circ} \mathrm{C}$} & 10 分 & 28 & 18 \\
\hline & & 20 分 & 40 & 26 \\
\hline \multirow{5}{*}{ 処方 -2} & $40^{\circ} \mathrm{C}$ & 20 分 & 22 & 13 \\
\hline & \multirow{2}{*}{$60^{\circ} \mathrm{C}$} & 10 分 & 27 & 16 \\
\hline & & 20 分 & 25 & 12 \\
\hline & \multirow{2}{*}{$80^{\circ} \mathrm{C}$} & 10 分 & 25 & 19 \\
\hline & & 20 分 & 37 & 30 \\
\hline \multirow{5}{*}{ 処方 -3} & $40^{\circ} \mathrm{C}$ & 20 分 & 27 & 20 \\
\hline & \multirow{2}{*}{$60^{\circ} \mathrm{C}$} & 10 分 & 38 & 20 \\
\hline & & 20 分 & 47 & 23 \\
\hline & \multirow{2}{*}{$80^{\circ} \mathrm{C}$} & 10 分 & 68 & 33 \\
\hline & & 20 分 & 65 & 33 \\
\hline \multirow{5}{*}{ 処方-4 } & $40^{\circ} \mathrm{C}$ & 20 分 & 27 & 21 \\
\hline & \multirow{2}{*}{$60^{\circ} \mathrm{C}$} & 10 分 & 39 & 22 \\
\hline & & 20 分 & 50 & 20 \\
\hline & \multirow{2}{*}{$80^{\circ} \mathrm{C}$} & 10 分 & 83 & 36 \\
\hline & & 20 分 & 88 & 40 \\
\hline
\end{tabular}

2）脱色率=末処理紙の浱度 $(100 \%)$ 一処理紙の 搌度 $(\mathrm{X} \%)$

3）測色機は Macbeth COLOR-EYE 3000

\section{4. 検討結果}

\subsection{Yellow-1（染色湌度：1.0\%）}

Yellow-1による結果を表 2 に示す。

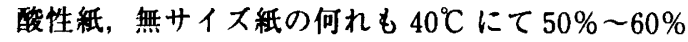
の脱色率を示し $80^{\circ} \mathrm{C}$ まで温度を上げると脱色率は更

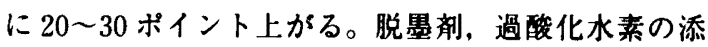
加量の関係はあまり出ていない。

予備的な試験として供試した同種属のYellow 染料 の中には表 3 の如く過酸化水素併用でも脱色事が非常
に低い染料もあり参考までに記载した（Yellow-2の 染色濐度 : $2.5 \%$ )。

\subsection{Red-1（染色湠度：2.5\%）}

Red-1 の結果を表 4 に示す。条件依存性が比較的大 きく，特に酸性紙において温度と過酸化水素の画方の 影響を受けており，処方 -4 の $80^{\circ} \mathrm{C}, 20$ 分では約 $90 \%$ の脱色率を示している。

\subsection{Blue-1（染色湌度：1.5\%)}

Blue-1の結果を表 5 に示す。条件依存性が比較的 大きく，特に酸性紙における過酸化水素の添加量に大 きな影篅を受けおり，処方 -4 の $80^{\circ} \mathrm{C}, 20$ 分では約 $90 \%$ の脱色率を示している。

Yellow-1 Ped-1に較べ無サイス紙より酸性紙で 
表 6 Blue-2 の結果

\begin{tabular}{|c|c|c|c|c|}
\hline \multirow{2}{*}{ 処 方 } & \multirow{2}{*}{ 温 度 } & \multirow{2}{*}{ 時 間 } & \multicolumn{2}{|c|}{ 脱色率（\%） } \\
\hline & & & 酸性紙 & 無サイズ紙 \\
\hline 未処理 & & & 基 準 & 基 準 \\
\hline \multirow{5}{*}{ 処方 -3} & $40^{\circ} \mathrm{C}$ & 20 分 & 55 & 27 \\
\hline & \multirow{2}{*}{$60^{\circ} \mathrm{C}$} & 10 分 & 86 & 36 \\
\hline & & 20 分 & 86 & 38 \\
\hline & \multirow{2}{*}{$80^{\circ} \mathrm{C}$} & 10 分 & 90 & 62 \\
\hline & & 20 分 & 92 & 59 \\
\hline \multirow{5}{*}{ 処方-4 } & $40^{\circ} \mathrm{C}$ & 20 分 & 55 & 26 \\
\hline & \multirow{2}{*}{$60^{\circ} \mathrm{C}$} & 10 分 & 89 & 38 \\
\hline & & 20 分 & 87 & 35 \\
\hline & \multirow{2}{*}{$80^{\circ} \mathrm{C}$} & 10 分 & 85 & 71 \\
\hline & & 20 分 & 92 & 83 \\
\hline
\end{tabular}

の脱色事が高くなっているがこれは染料のパルプへの 親和性が若干低い事に起因しているものと思われ未染 着染料が磌酸バンドによって顔料化されてパルブに染 着せずそのままパルブに抄き込まれ，一見浱度感は得 られるものの, 跘量处理によってその顔料化されたも のが取り除かれるためと推测される。

予備的な試験として供試した同種属の Blue 染料の 中には表 6 の如く酸性秖ではほほ完全に脱色可能な染 料もあり参考までに記载した（Blue-2の染色浱度： $2.0 \%)$ 。

5. まとめ

（1）同じ種属，また同じ色相でも染料によってかな ク大きな品質差がある。
（2）脱色の要因としては温度が最も影㽚を受ける。

（3）酸性紙と中性紙では酸性紙の方が脱色はし易い。

6. むすび

今回の試験条件は対象とした銘柄数, 脱墨処理の薬 品添加量, 温度や時間ごく限られた範囲でのものであ り実用性という点では内容的にまだまだ不分である。 従来, 染料メーカーにおける新製品開発はより高い 染色性とより高い堅审性を目指して行われてきており， 染着したものをいかにして再加工が可能な形にするか は極めて難しい課題ではあるが, 環境改善やリサイク ルの推進という観点から，染料メーカーとして“染色 と脱色”を一体として考えることは今後避けては通れ な重要なテーマであると考え検討を深めていきたい。 


\section{報文概要 一 覧 \\ 省エネ機器の採用による DIP 設備と最近の省エネ事例}

中越バルブ工業株式会社 能町工場施設部電気計装課 芳野 知樹

当工場ではインバータ化を皘極的に進めて実績をあげてきましたが，平成 10 年 7 月より塗工設備（実

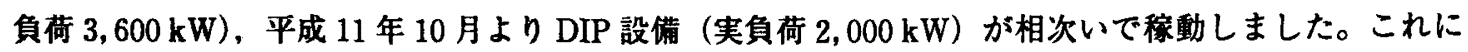
より当工場の使用電力量が月当たり $35,300 \mathrm{MWh}$ から $37,600 \mathrm{MWh}$, 月間最大電力が $57,000 \mathrm{~kW}$ から $61,500 \mathrm{~kW}$ に增加しました。 また品質向上や瑔境関係設備で逆に增エネになる可能性もあるので, 新設 借設置段階より回転数制御可能機器の検討・調査をし, さらに省エネ型高効率のモーター及び機器を導 入する事を提案してきました。今回は，その計画と効果の確認と既設設備の省エネ実績をテーマに選定 しました。

(本文 89 ベージ)

\section{脱墨条件における有色染料の脱色性}

\section{日本化省株式会社 色材研究所 营谷 邦夫}

近年, 環境問題が世界的にも大きくクロースアップされている中で，製紙業界に於いても自然保護を 推進する上で, 古紙のリサイクルへの気運は年々高まっており脱墨処理設備の建設も皘極的に行われて いる。

紙製品には增白用の蛍光染料や色上質紙の着色用に有色染料が広篹囲で使用されており,リサイクル する上で，これらの染料が少なからず影稫を与えていることは事実である。

現状, リサイクル古紙として対象となる原料古紙は新䦥紙, 雑誌等が主体であり有色染料が関わる色 上質紙等の分野は比较的少ないと思われるが，有色染料の脱色性についても一つのテーマであると考え る。

過去にも酸化法，缱元法での検討はされているが，今回，脱墨処理条件におけるアニオン性直接染料 の脱色性について検討してみた。

(本文 96 ページ)

\section{超音波顕微鏡を用いたパルプ織維壁の弾性係数測定}

\section{東京大学大学院 晨学生命研究科生物材料科学専攻製紙科学研究室 カンタヤーヌウオン ソムワン, 江前敏晴，尾鍋史彦}

走査型超音波顕微鏡（SAM）を用いてパルブ䋞維壁の弾性係数を測定した。超音波材料シタニチャ (AMS) と呼ばれる，材料に特有の超音波の干涉図からこの計算が可能となる。熱処理した樴維及び未 処理の織維の横断面を調製し，この断面の表面を走るレイリー波の速度を測定すると，それそれ 3,520 $\pm 170 \mathrm{~m} / \mathrm{s}$ 及び $3,240 \pm 180 \mathrm{~m} / \mathrm{s}$ であった。これは, レイリー波の速度が速いほど弾性係数 $\left(C_{44}\right)$ が大 きくなることから考えて，熱処理した樴維の瀻維壁は未処理の緉維に比べて堅くなったことを意味する。 さらに，緁維は放射方向に等方体と考えられる $\mathrm{S}_{2}$ 層が主成分であると考えると，レイリー波の速度は, 岦断波の速度の 0.93 倍に相当し, セルロースの真密度が $1.5 \mathrm{~g} / \mathrm{cm}^{3}$ であるという条件を適用すること ができる。すると，熱処理した緎維及び未処理の緉維の峨維壁弾性係数 $\left(C_{44}\right)$ は，それぞれ $22 \pm 2 \mathrm{GPa}$

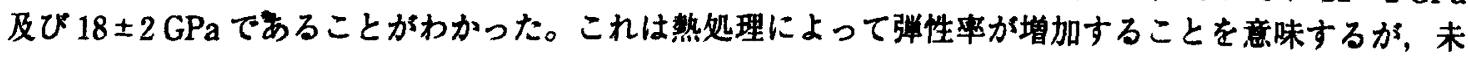

